УДК 378:[373.3+004]

Кучаковська Галина Андріївна

викладач кафедри інформаційних технологій і математичних дисциплін

Київський університет імені Бориса Грінченка, м. Київ, Україна

h.kuchakovska@kubg.edu.ua

\title{
РОЛЬ СОЦІАЛЬНИХ МЕРЕЖ В АКТИВІЗАЦЇ̈ ПРОЦЕСУ НАВЧАННЯ ІНФОРМАТИЧНИХ ДИСЦИПЛІН МАЙБУТНІХ ВЧИТЕЛІВ ПОЧАТКОВОЇ ШКОЛИ
}

\begin{abstract}
Анотація. У статті проаналізовано підходи до використання соціальних мереж у процесі навчання інформатичних дисциплін майбутніх вчителів початкової школи; описано дидактичні можливості використання соціальних мереж під час проведення лекційних та практичних занять з інформатичних дисциплін; проаналізовано та представлено результати анкетування студентів спеціальності «Початкова освіта» щодо використання соціальних мереж в навчальній діяльності та повсякденному житті; проведено статистичний аналіз результатів педагогічного експерименту щодо впровадження соціальних мереж у навчальний процес майбутніх вчителів початкової школи.
\end{abstract}

Ключова слова: навчальний процес; майбутні вчителі початкової школи; інформаційне суспільство; інформатичні дисципліни; ІКТ; хмаро орієнтовані технології; соціальні мережі.

\section{1. ВСТУП}

Постановка проблеми. В умовах становлення інформаційного суспільства сучасний стан розвитку освіти потребує нового методологічного рівня викладання дисциплін у вищих навчальних закладах, що сприяв би кращій підготовці висококваліфікованого, компетентного та конкурентоспроможного вчителя початкової школи. Такий педагог повинен поєднувати фахові знання та організаторські вміння, майстерно використовувати різні методики навчання та викладання, бути IKграмотним, вирішувати складні завдання виховного процесу.

У зв'язку 3 висуненням перелічених вище вимог до майбутнього педагога необхідно активізувати пізнавальну діяльність студентів шляхом використання сучасних інформаційних технологій. Такий підхід задекларовано у Стратегії розвитку інформаційного суспільства в Україні на 2013-2020 pp. [16]. Національна стратегія розвитку освіти України на період до 2021 року [12] визначає необхідність спрямування діяльності педагогічних працівників на пошук нових моделей організації навчання та формування безпечного освітнього середовища, створення інформаційної системи підтримки освітнього процесу, спрямованої на здійснення її основних функцій та забезпечення навчально-виховного процесу засобами інформаційно-комунікаційних технологій, а також доступу навчальних закладів до світових інформаційних ресурсів.

3 огляду на стратегії модернізації освітнього процесу необхідно враховувати соціальне замовлення сучасного суспільства та вимоги ринку праці, специфіку інформатичних дисциплін на різних спеціальностях, цілі навчальної діяльності, потреби сучасного студента та його індивідуальні психологічні особливості. Тому на заняттях важливо поєднувати різні методики навчання та активізовувати навчальний процес різними шляхами - активно (коли викладач відіграє роль наставника в освітній діяльності та використовує активні методи навчання: проблемне навчання, програмоване навчання, студентоцетричний підхід, навчання на дослідницькій основі 
тощо) та цілеспрямовано (добір змістового наповнення навчального матеріалу, методів, форм та засобів навчання, діагностика результатів навчальної діяльності студентів).

Активізація процесу навчання, на думку Лузана П.Г. [10], визначається як удосконалення методів і організаційних форм навчально-пізнавальної роботи, що забезпечують активну й самостійну теоретично-практичну діяльність студентів у всіх ланках освітнього процесу. Підтримуючи думку дослідника водночас вважаємо, що це можна досягти шляхом впровадження та використання сучасних інформаційнокомунікаційних технологій (ІКТ), зокрема соціальних мереж.

Аналіз останніх досліджень та публікацій свідчить, що особливості використання інформаційно-комунікаційних технологій у вищій та середній школі досліджувалися в роботах багатьох учених, зокрема С. Архангельського, Н. Воропай, О. Горячева, М. Жалдака, А. Коломієць, Т. Корольової, Ю. Машбиця, Н. Морзе, Л. Петухової, Й. Ривкінда, О. Співаковського, О. Спіріна, О. Суховірського, Н. Тверезовської, І. Шапошнікової, О. Шиман та ін.

Дослідження проблем впровадження в освітню галузь України хмарних технологій пов'язані з іменами таких учених як В. Биков, В. Гриценко, М. Жалдак, С. Литвинова, В. Михалевич, А. Манако, С. Семеріков, А. Стрюк, М. Шишкіна та ін.

Вагомий внесок у вивчення можливостей використання соціальних сервісів у навчально-виховному процесі зробили такі науковці: О. Андрєєв, Н. Балик, Є. Патаракін, М. Рєзнін, В. Стародубцев, М. Менякіна; питання використання освітніх віртуальних спільнот викладачами висвітлено в роботах І. Малицької, М. Остапенко, І. Іванюк, А. Яцишин та ін.

Дослідження теоретичних основ використання IКТ в освіті висвітлені в роботах таких закордонних вчених: С. Григорьєва, В. Гришкуна, М. Бухаркина, Дж. Мерредіт, Е. Машбіц; практикою впровадження ІКТ в освітній процес займалися Є. Діканський, I. Петров, А. Марков; дидактичний потенціал інформаційних технологій вивчали I. Роберт, В. Трайньов, Е. Харітонов та ін.

Можливості використання соціальних мереж та хмаро орієнтованих технологій в навчальному процесі досліджували закордонні вчені В. Глухих, Г. Левкин, I. Кречетнікова., А. Парабіна, Т. Пустовой, А. Фещенко, Р. Бергер (R. Berger), A. Нейхолд (A. Nijholt), В. Кюма (V. Kumar), М. Амбруст (M. Armbrust), К. Субраманіан (K. Subramanian) та ін.

Проблемою впровадження IКТ в процес навчання майбутніх вчителів початкової школи займалися такі вчені: Н. Воропай, С. Гунько, І. Доніна, О. Кравчук, Н. Листопад, О. Майборода, Ю. Первін, А. Семенов, В. Шевченко та ін.

Аналіз джерельної бази показав, що попри значні досягнення вітчизняних i закордонних дослідників у вивченні проблем впровадження інноваційних технологій в навчальний процес, все ж роль соціальних мереж в активізації процесу навчання інформатичним дисциплінам майбутніх вчителів початкової школи не знайшла достатнього обгрунтування.

Метою статті є обгрунтування основних напрямів використання соціальних мереж в процесі навчання інформатичним дисциплінам майбутніх вчителів початкової школи та визначення їх ролі в активізації навчальної діяльності студентів.

\section{2. МЕТОДИ ДОСЛІДЖЕННЯ}

Під час дослідження були використані такі методи: аналіз науково-педагогічної і методичної літератури щодо сутності активізації процесу навчання інформатичним дисциплінам майбутніх вчителів початкової школи; аналіз державних нормативних документів, навчальних програм, он-лайн ресурсів, педагогічних програмних засобів 
тощо; порівняння, вивчення та узагальнення педагогічного досвіду щодо покращення процесу навчання інформатичним дисциплінам майбутніх вчителів початкової школи у системі професійної підготовки, а також організації педагогічного процесу 3 використанням IКТ у вищий школі; анкетування студентів спеціальності «Початкова освіта» для визначення стану використання соціальних мереж у процесі навчання інформатичним дисциплінам.

Робота над матеріалом статті велася в рамках наукової теми Київського університету імені Бориса Грінченка «Філософські, освітологічні та методичні засади компетентнісної особистісно-професійної багатопрофільної університетської освіти», ДР № 0110U006274.

До участі в педагогічному експерименті залучено студентів спеціальності 8.01010201 «очаткова освіта».

\section{3. РЕЗУЛЬТАТИ ДОСЛІДЖЕННЯ}

Отримання якісної вищої педагогічної освіти є однією з найважливіших гарантій реалізації громадянами їх інтелектуального потенціалу, вирішальним фактором економічної стабільності та одним 3 показників рівня викладання дисциплін в загальноосвітніх та вищих навчальних закладах. Студент, по закінченню ВН3, повинен бути висококваліфікованим фахівцем (детально про проблему вибору спеціальності та профорієнтаційної роботи з учнями описано в наших попередніх роботах [8] та [9]), компетентним не тільки у своїй професійній діяльності, а й у суміжних галузях знань. В умовах створення інформаційного суспільства до необхідних компетентностей вчителя початкової школи додається ІК-компетентність, компоненти якої висвітлено в роботі Д. М. Бодненка [3]. Наведемо деякі з них:

- володіння навичками інформаційної навігації;

- знання основ телекомунікаційного етикету;

- вміння користуватися комплексом послуг, що надаються інформаційним середовищем;

- знання специфіки роботи 3 інформаційними ресурсами (бази даних, інформаційні служби);

- вміння активно використовувати комунікаційні можливості комп'ютерних мереж 3 метою організації плідного спілкування між учасниками дистанційного навчального процесу;

- володіння та використання в професійній діяльності мережних сервісів.

Ці компоненти набувають особливої актуальності за умов постійного процесу інформатизації життя учнів початкових класів (учитель початкової школи повинен вміти спілкуватись 3 дітьми мовою мережних сервісів).

Важливу роль у розвитку таких компонентів ІК-компетентності відіграє активізація процесу навчання майбутніх вчителів початкової школи в процесі вивчення інформатичних дисциплін, що реалізується через інформатизацію процесу навчання, удосконалення його форм та змісту, впровадження комп'ютерно-орієнтованих методів навчання та контролю знань, використання сучасних засобів створення навчального контенту та мережних інструментів відкритої освіти.

Активізації навчального процесу сприяє реалізація індивідуального та диференційованого підходів, розвиток творчої особистості студента за рахунок використання в навчальному процесі мультимедійних технологій, прикладних програм, засобів моделювання, наочних елементів, постановки проблемних завдань, відтворення виробничих ситуацій та презентації висновків, демонстраційного експерименту, постійної самостійної роботи з новою літературою, дискусій у ході занять, а також 
упровадження інтерактивних елементів дослідницької діяльності в навчальний процес $[11,2]$. Також зазначимо, що активізація навчання студентів повинна бути спрямована на пожвавлення пізнавального процесу та збільшення мотивації до навчання, здатності кваліфіковано та професійно розв'язувати поставлені задачі, формування нестандартного стилю мислення.

В аспекті використання інформаційно-комунікаційних технологій в навчанні до найважливіших чинників активізації навчально-пізнавальної діяльності студентів відносять такі [4, 11]:

- розвиток мотивації (посилення інтересу до навчання), у тому числі до способів одержання знань;

- розвиток мислення та інтелектуальних здібностей студентів;

- індивідуалізація та диференціація навчання;

- розвиток самостійності;

- надання переваги активним методам навчання;

- підвищення рівня унаочнення;

- створення та розміщення у відкритому доступі якісних електронних освітніх ресурсів.

Мережні інструменти відкритої освіти визначаються як засоби IКT, що забезпечують формування й підтримування в актуальному стані мережних електронних інформаційних ресурсів відкритого навчального середовища, реалізації технологій проектування і застосування відкритих педагогічних систем. Актуальними для нас $є$ такі інструменти як: технології електронного дистанційного (е-дистанційного) навчання, глобальні соціальні мережі, науково-освітні інформаційні мережі, технології підтримки взаємозв' язку з використанням мобільних Інтернет-пристроїв та інші $[15,3]$.

Упровадження мережних технології в освітній процес $\epsilon$ перспективним напрямом теорії навчання, що грунтуються на таких положеннях:

- навчання визначається інструментами та об'єктами, якими користується студент. Дії над об'єктами вимагають спілкування. Це спілкування з приводу дій і об'єктів має першорядне значення для навчання;

- навчання визначається середовищем, у якому відбувається засвоєння нових знань студентом, і головним $є$ те, що потрібно не тільки сприймати й споживати інформацію, але діяти активно, одержуючи результат як винагороду за свої дії;

- навчання відбувається в певній групі соціальної мережі, де недосвідчені студенти поступово стають експертами через практичну участь у розв'язанні проблем в межах конкретної галузі знань [17,3].

Широке використання сучасних інформаційно-комунікаційних технологій в навчальному процесі дає можливість розкрити значний гуманітарний потенціал всіх дисциплін, завдяки формуванню наукового світогляду, розвитку аналітичного i творчого мислення, суспільної свідомості й свідомого ставлення до навколишнього світу [5].

Використання соціальних мереж може надати навчальному процесу більшої інтерактивності, позитивно вплинути на результати пізнавальної діяльності студентів, стати ефективним засобом підвищення мотивації та якості навчання, організації колективної роботи студентів, виконання спільної проектної діяльності, індивідуалізувати віртуальний навчальний простір студента. Також соціальні мережі можна використовувати як засіб поширення навчального матеріалу.

Соціальна мережа визначається як соціальна структура, що складається з групи вузлів, якими є соціальні об' єкти (люди), і зв'язків між ними (комунікація в соціальних мережах). Соціальну мережу можна трактувати як багатопрофільний веб-сайт, контент 
якого наповнюється самими учасниками мережі. Сайт являє собою автоматизоване соціальне середовище, що дозволяє спілкуватися групі користувачів, об'єднаних спільними інтересами [12]. Головним принципом об'єднання користувачів у соціальну мережу є їх спільні інтереси, фінансове становище, стать, приналежність до тієї чи іншої раси, національності, віросповідання, професії і т.д.

В умовах бурхливого розвитку інформаційно-комунікаційних технологій нові соціальні сервіси, що з'являються в мережі Інтернет, можуть стати одним із засобів, що видозмінять процес навчання. Їх функціональне об'єднання може призвести до того, що учасники освітнього процесу зможуть максимально швидко та зручно оперувати навчальним контентом не виходячи з дому та витрачати на це мінімум зусиль $i$ часу. Існуючі соціальні сервіси можна згрупувати за спільними ознаками: для збереження фото- та відеофайлів (Flikr, Flamber, FilkLab), сервіси для спільної роботи 3 документами (GoogleDocs, Dropbox, OneDrive), сервіси 3 можливістю спільного редагування та зміни змістового наповнення (Blogger, Wiki), сервіси для комунікації та розваг - соціальні мережі (Facebook, Twitter, ВКонтакте, Одноклассники), геосервіси (GoogleMaps, GoogleEarth, Wikimapia) [7, 1].

Соціальні мережі стали невід'ємною частиною життя кожної сучасної людини, зокрема молодої аудиторії - студентів. За даними досліджень американської компаніїрозробника програмного забезпечення Adobe [13] число зареєстрованих користувачів у всесвітній мережі «Facebook» перевищує 1,4 млн., Інтернет-сервіс «YouTube» налічує 1 млр. аккаунтів, в російській мережі «ВКонтакте» зареєстровано 228 млн. користувачів. Вітчизняну статистику висвітлює Інтернет-видання Обозреватель.иа за даними пошуку по блогах «Яндекс» [19]. Так, у 2014 р. в порівнянні з 2013 р. на 3,1\% збільшилася кількість Інтернет-користувачів на території України. Загальна кількість користувачів мережі Інтернет - це здебільшого працездатна молодь України у віці 16-35 років, що складає 43\% від кількості всього населення. Найпопулярнішою соціальною мережею $є$ російська мережа «ВКонтакте»- в ній зареєстровано 27 млн. аккаунтів, на другому місці «Одноклассники»- 11 млн., третє місце посідає американська соціальна мережа «Facebook» - 3,2 млн. користувачів, на четвертому місці значиться блог-мережа «Twitter» - 430 тис. аккаунтів. За даними Пошуку у блогах «Яндекс», більшість українських користувачів соціальної мережі «Одноклассники» - це молодь у віці 25-35 років, а соціальної мережі «ВКонтакте» - підлітки та молодь віком від 16 до 25 років (див. Рис.1). Українська аудиторія «Одноклассники» в цілому старше, ніж аудиторія «ВКонтакте». Так, результати Пошуку показують, що більше 40\% аудиторії «Одноклассники» складають користувачі після 35 років, а в «ВКонтакте» їх всього $15 \%$.

\section{Віковий склад українських користувачів соціалної мережі "Вконтакте"}

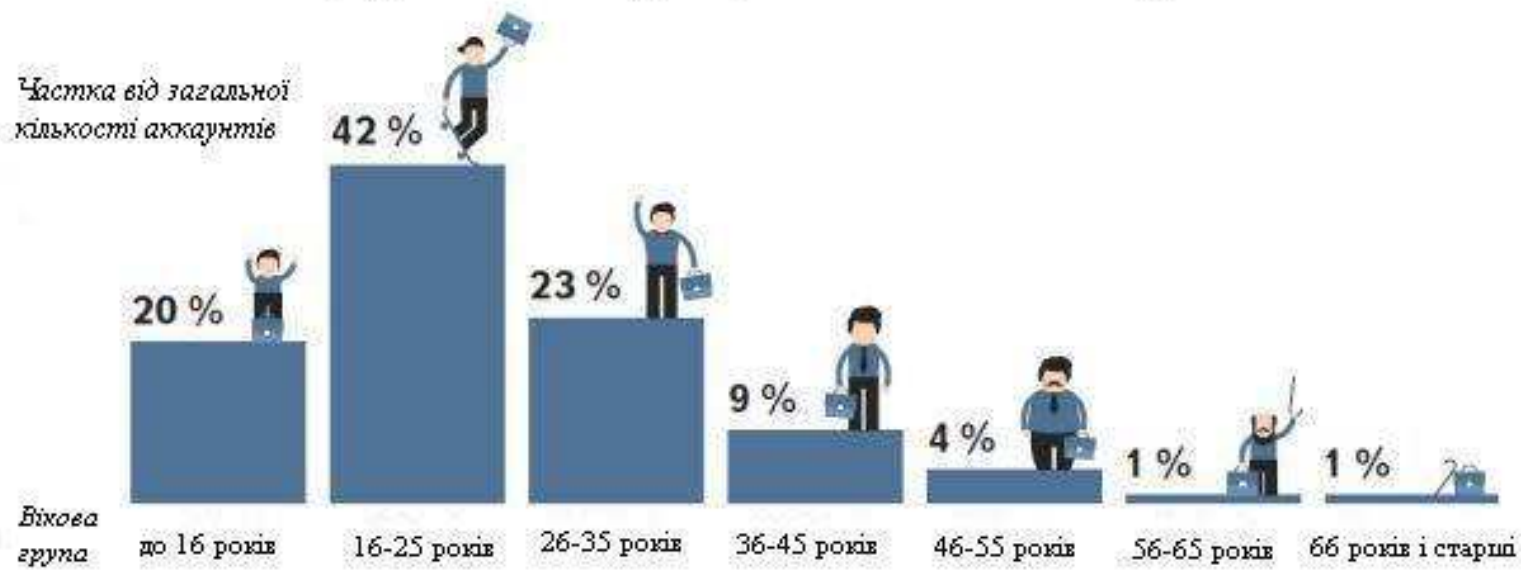




\section{Віковий склад українських користувачів соціаљної мережі "Одноклассннки"}

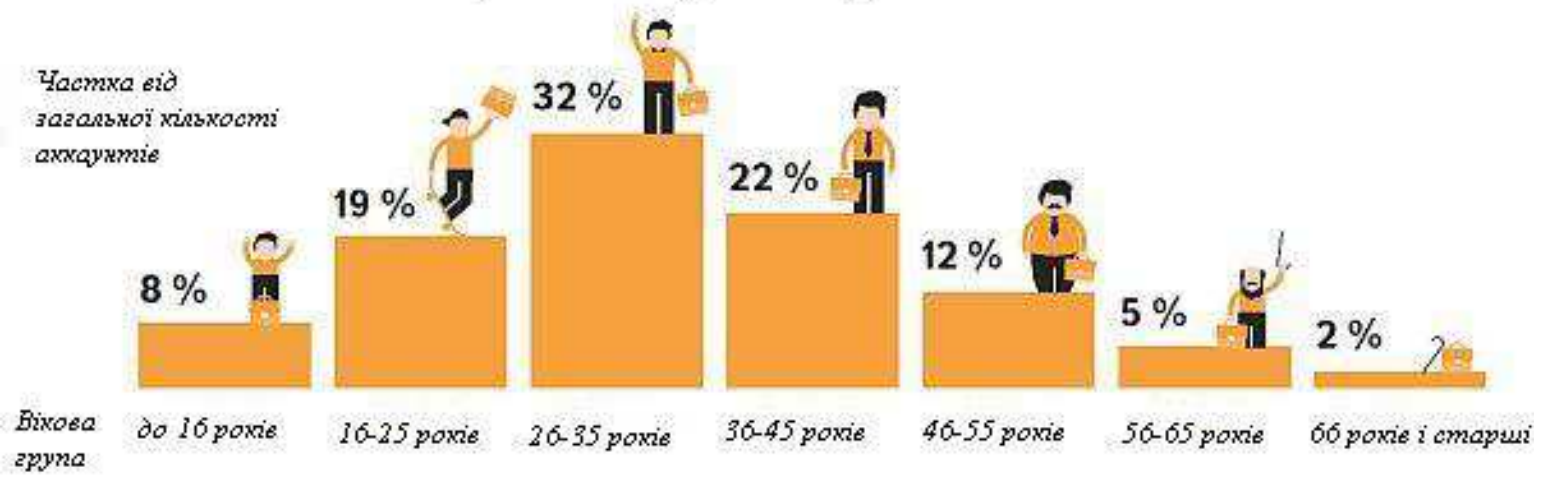

Рис. 1 Віковий склад украӥнських користувачів сочіальних мереж «ВКонтакте» та «Одноклассники»

Соціальні мережі привабливі тим, що до них можна отримати доступ з будь-якого пристрою. Вони мають простий користувацький інтерфейс, до якого звикла молодь; вони інтегрують безліч додаткових сервісів, які можна використовувати для створення власного навчального контенту. Все це дозволяє заощадити час, минаючи етап адаптації студентів до нового комунікативного простору. Мультимедійність комунікативного простору полегшує завантаження і перегляд у віртуальній навчальній групі відео- та аудіоматеріалів [6].

Поряд з цим існує думка, що соціальні мережі відволікають від начального процесу та не можуть стати додатковим педагогічним засобом, оскільки традиційно є віртуальним місцем проведення вільного часу. Однак не можна заперечувати, що впроваджуючи в навчальний процес соціальні мережі можна ефективно організовувати колективну роботу, проектну діяльність та самоосвіту студентів. Фещенко А. С. в своїй роботі висунув низку аргументів на користь використання соціальних мереж в освітній діяльності $[18,46]$ :

1. Соціальні мережі популярні серед молоді.

2. Використання соціальних мереж не потребує грошових затрат. Соціальні мережі надають безкоштовне користування сервером для зберігання цифрових даних.

3. Використовуючи соціальні мережі як засіб навчання, студенти набувають навички, зумовлені викликами XXI століття, а саме, оволодіння засобами і способами комунікації 3 іншими людьми, вміння правильно та творчо використовувати дані для вирішення проблем.

4. Спільна робота 3 цікавими веб-ресурсами стає ще більш зручною. Використовуючи соціальну мережу студенти та викладачі можуть обмінюватися й обговорювати цікаві знахідки в мережі Інтернет.

5. Впровадження соціальних мереж в навчальний процес дозволить студентам, відсутнім з тих чи інших причин на аудиторному занятті, спостерігати за навчальною роботою і брати в ній участь в режимі он-лайн.

6. Можливість постійної взаємодії студентів і викладачів в мережі (в зручний для них час) забезпечує безперервність навчального процесу.

7. Використовуючи соціальні мережі у викладача з'являється можливість проводити аудиторні лекційні заняття в інтерактивному режимі. Наприклад, якщо лекція проходить в он-лайн режимі, у соціальній мережі «Twitter» 
студенти в процесі прослуховування лекції можуть ставити питання i обговорювати представлений матеріал у форматі мікроблогу.

8. Віртуальна група, створена в соціальній мережі, доступна для студентів скрізь, де б вони не знаходилися, за умови використання мобільного Інтернету.

9. Можливість спільного створення та удосконалення навчального контенту. Студенти замість простого споживання інформації стають тьюторамиекспертами в середовищі віртуальної навчальної групи (створюють повідомлення, дискусії, ресурси і багато іншого).

10. Соціальна мережа дозволяє викладачеві краще запам'ятовувати студентів (співвідносити імена й обличчя в аудиторії) і розуміти їх інтереси. У викладачів з'являється можливість дізнатися більше про особистість студента, його індивідуальні особливості та запропонувати йому інформацію, теми або завдання, які повинні його зацікавити.

Попри низку переваг, пов'язаних 3 упровадженням соціальних мереж в навчальний процес, доцільно зазначити проблеми, що супроводжують їх використання. Зокрема, необхідність постійного доступу до мережі, дотримання етикету спілкування серед учасників, відсутність можливості постійно контролювати використання соціальних мереж саме в навчальних цілях та ін. Окрім цього, викладач не зажди зможе встигати прослідковувати коректність навчальних матеріалів, які завантажують студенти.

У працях Бикова В. Ю. [1,2] підкреслено, що дуже важливою є реакція учня (в нашому випадку студента) на змістово-функціональні компоненти навчального середовища, на інформаційні ресурси, до яких йому надається доступ. Робота з тими чи іншими інформаційними ресурсами може викликати у студента реакцію їх відторгнення чи блокування, а може привести до переоцінювання сформованих цінностей студента. Одні з них можуть викликати в студента підйом духовних сил, а інші - привести до повної втрати інтересу до навчання.

У рамках дослідження експериментально впроваджено соціальну мережу «ВКонтакте» в навчальний процес на базі Київського університету імені Бориса Грінченка в групі студентів спеціальності «Початкова освіта». Було створено окрему групу, в яку додавалися матеріали лекцій та лабораторних робіт, створювалися тематичні бесіди за певним завданням, де студенти разом з викладачем обмінювалися думками та роз' яснювали окремі аспекти проблеми, висували ідеї модернізації самого процесу навчання та ін..

3 огляду на таку модель побудови начального процесу, змінюється роль педагога. Викладач перетворюється 3 «ретранслятора» знань на співтворця сучасних технологій навчання $[2,1]$.

Під час проведення навчальних занять 3 дисципліни «Інформаційні технології навчання», намагаючись поєднати сучасні психолого-педагогічні та інформаційнокомунікаційні технології, для студентів заздалегідь надавався доступ до навчальнометодичного комплексу з окремої теми (відео-, фотоматеріали, документи та інші матеріали). Студенти опрацьовували ці дані, після чого безпосередньо на занятті відбувалось обговорення проблемних питань, уточнення незрозумілого (неоднозначного) матеріалу.

У рамках такої роботи паралельно використовувалися сервіси GoogleApps. Студенти, скооперувавшись, спільно виконували завдання, вели дослідницьку діяльність (при виконанні індивідуального навчально-дослідного завдання, студенти залучали до спільного обговорення робіт своїх одногрупників, додавали коментарі та критику; при використанні календаря планували спільну групову діяльність; 
створюючи анкети, проводили соціальні опитування та вчилися аналізувати отримані результати), що розвивало у них відчуття команди та підтримки (колаборації).

Наведемо приклад статистичного аналізу результатів реалізації експерименту у процесі викладання навчальної теми «Технологія створення матеріалів для організаційної діяльності майбутнього фахівця засобами електронних таблиць» в межах курсу «Інформаційні технології навчання». Шляхом евристичної бесіди (для бліцопитування використовувалися технології SmartBoard, GoogleDocs), проведеної на лекційному занятті, було визначено більш ефективний засіб подання матеріалу. Для контрольної групи (64 особи) на самостійний розгляд теми був представлений матеріал в системі Moodle; для експериментальної групи (66 осіб) крім матеріалів в системі Moodle було здійснено підтримку навчального процесу з використанням соціальної мережі «ВКонтакте». За результатами підсумкового тестування учасників контрольної та експериментальної груп за окресленою темою були отримані дані, які після перевірки статистичної гіпотези 3 використанням $t$-критерію Стьюдента, показали результат: $5,11=t_{\text {емn }}>t_{\kappa p}(0,01 ; 63)=2,66$ при рівні значущості $\alpha=0,01$. Це означає, що нульова гіпотеза про відсутність різниці між середнім результатом рішення тестових завдань в обох групах при рівні значущості 0,01 відхиляється. Тобто, можна говорити про різний рівень вирішення тестових завдань 3 теми «Технологія створення матеріалів для організаційної діяльності майбутнього фахівця засобами електронних таблиць» студентами з контрольної та експериментальної груп. Зокрема відмінність полягала в тому, що рівень опанування матеріалу студентами, які використовували соціальну мережу «ВКонтакте», мав вищий результат (див. Рис.2).

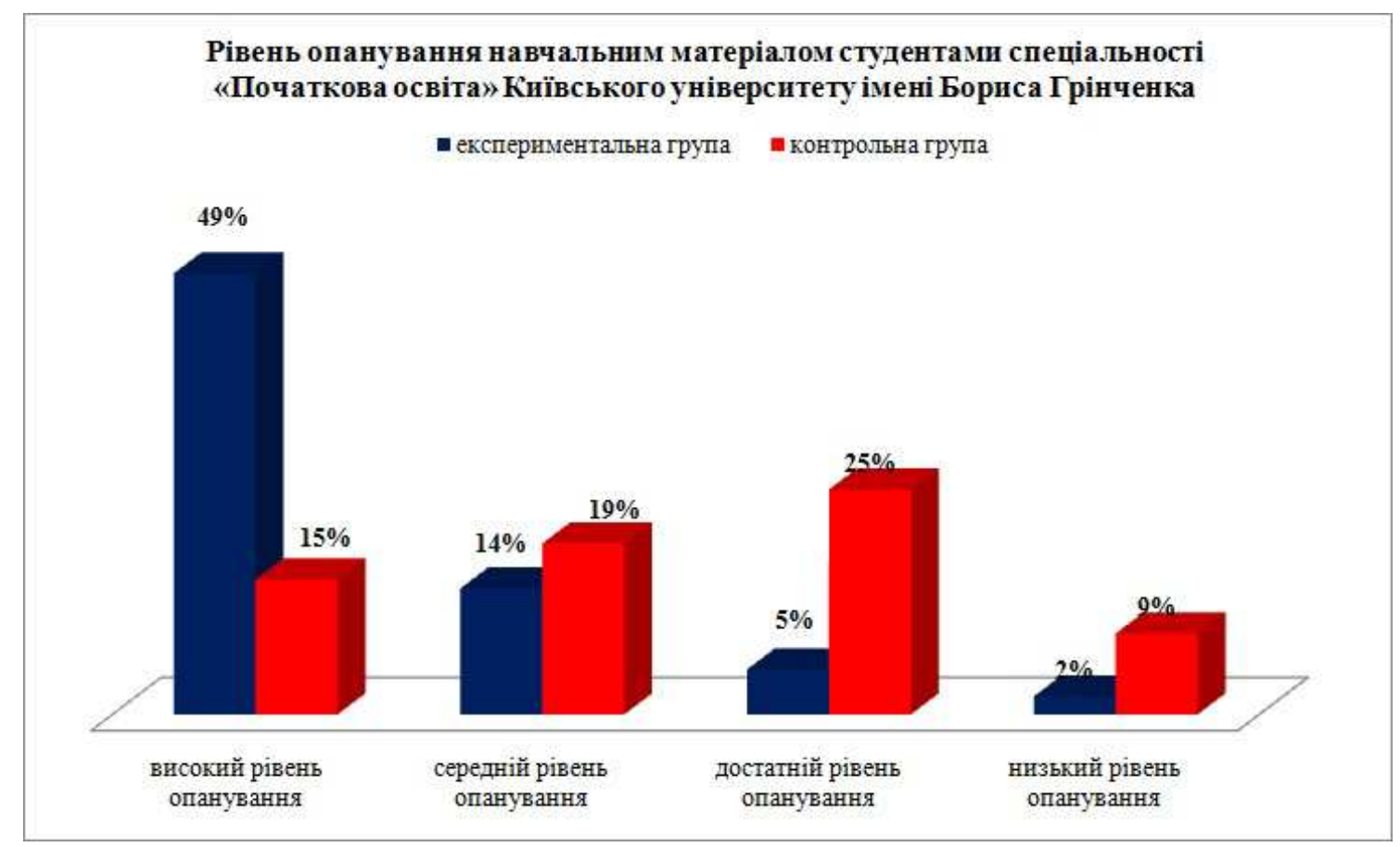

Рис.2. Рівень опанування навчального матеріалу студентами спеціальності «Початкова освіта» Київського Університету імені Бориса Грінченка

У межах дослідження також було проведено соціологічне опитування серед 188 студентів 1-го курсу спеціальності «Початкова освіта». Анкетування мало на меті дослідити чи мають студенти постійний доступ до мережі Інтернет, де вони їм користуються та який пристрій використовують. 
Результати, наведені на Рис. 3 та Рис. 4, свідчать, що більшість студентів мають постійний доступ до мережі Інтернет (94\%), використовують його вдома (85\%), і лише $6 \%$ не мають доступу до мережі. $52 \%$ опитуваних користуються смартфонами, $41 \%$ ноутбуками.

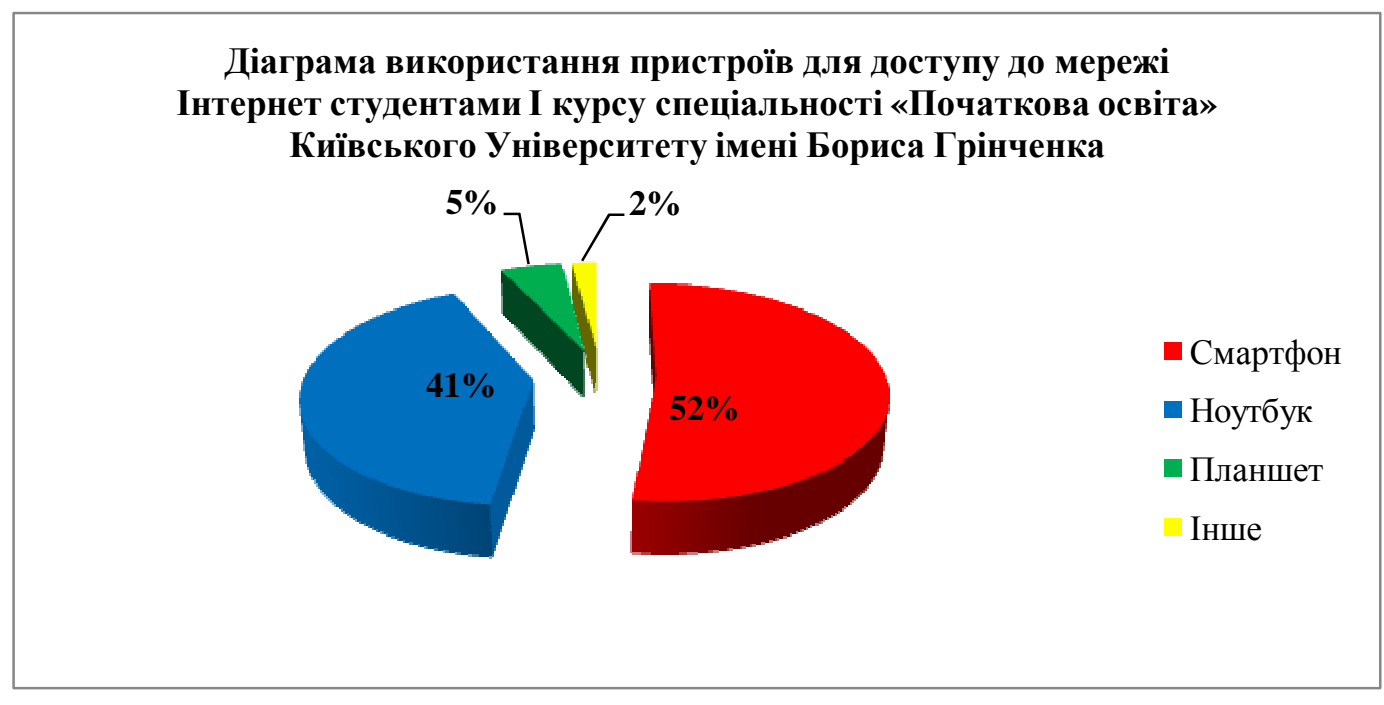

Рис. 3. Діаграма використання пристроїв для доступу до мережі Інтернет студентами I курсу спеціальності «Початкова освіта» Київського Університету імені Бориса Грінченка

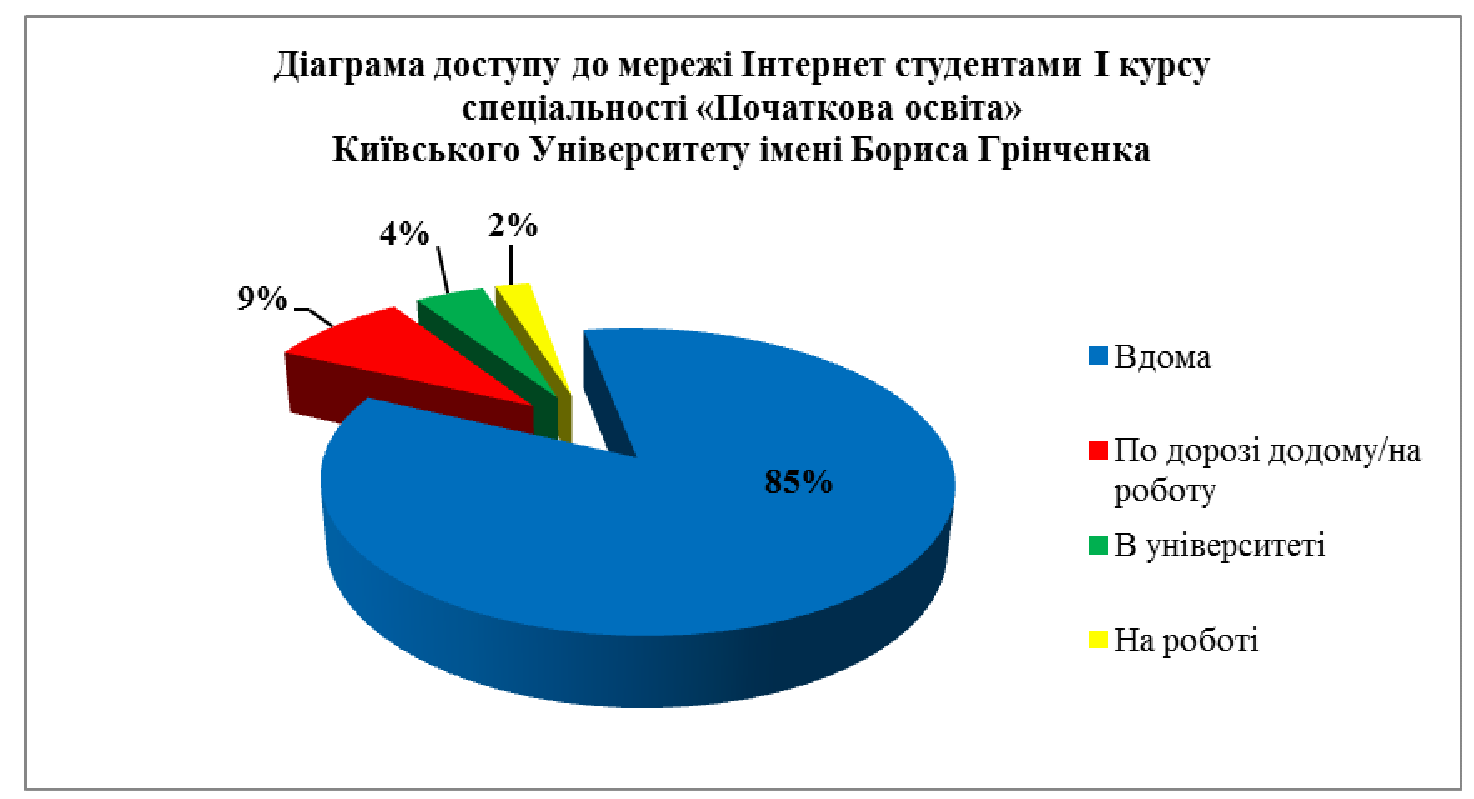

Рис. 4. Діаграма доступу до мережі Інтернет студентами I курсу спеціальності «Початкова освіта» Київського Університету імені Бориса Грінченка

Більшість опитуваних студентів користуються соціальною мережею «ВКонтакте» - 46\%, «Instagram»-14\%, інша частина користуються «Skype» та «Twitter» (див. Рис. $5)$. 


\section{Діаграма використання соціальних мереж студентами I курсу спеціальності «Початкова освіта» Київського Університету імені Бориса Грінченка}

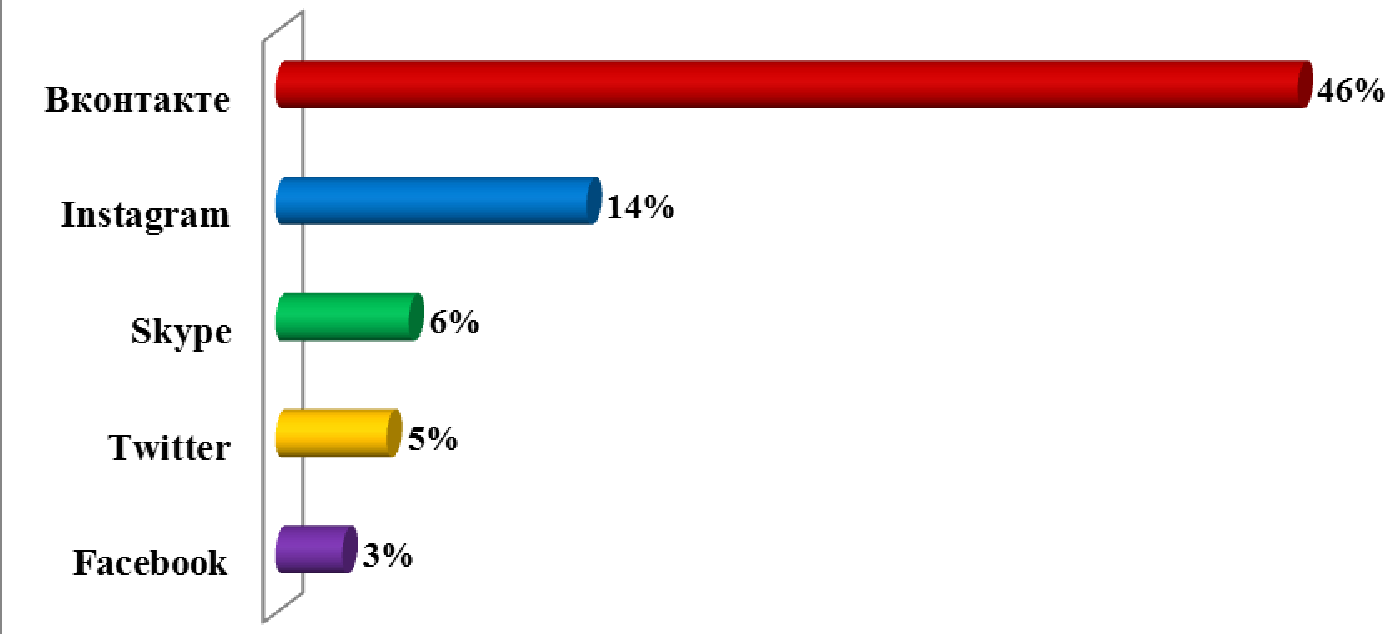

Рис. 5. Діаграма використання соиіальних мереж студентами I курсу спеціальності «Початкова освіта» Київського Університету імені Бориса Грінченка

Результати опитування показали, що більше $50 \%$ студентів використовують соціальні мережі для спілкування, прослуховування музики та перегляду фільмів, 8\% для самореалізації, участі в соціальних проектах та пошуку роботи. I тільки $11 \%$ намагалися використовувати соціальні мережі для навчання. Студенти притримуються думки, що соціальні мережі краще використовувати для оперативного доступу до навчально-методичних матеріалів, зв'язку 3 викладачем та колективного виконання домашнього завдання, проведення занять в дистанційному режимі та самостійного наповнення навчального контенту. Для цього, на їх думку, більш придатні такі мережі як «ВКонтакте», «Facebook», блог-платформа «Живий журнал» та програма «Skype».

Організовуючи навчальну діяльність майбутнього вчителя початкової школи в умовах вивчення інформатичних дисциплін, можна використовувати соціальні мережі для вирішення наступних завдань:

- організовувати колективну роботу студентів на занятті та за межами аудиторії, що сприяє співпраці, набуттю досвіду роботи в команді;

- розширювати організацію навчання студентів удома, оскільки соціальні мережі дозволяють використовувати навчальний контент не обмежуючись часовими, географічними та віковими межами;

- забезпечувати розвиток персоніфікованого навчального середовища студента, створення його портфоліо та навчального контенту дисциплін. Якщо студенти разом з викладачем будуть створювати навчальний контент дисципліни, він буде адаптований індивідуально для кожного студента;

- сприяти самостійному навчанню студентів (реалізація принципів навчання на дослідницькій основі);

- сприяти індивідуальному навчанню студентів, оскільки кожному студенту необхідно працювати в своєму ритмі;

- здійснювати неформальне спілкування між викладачем та студентом;

- організовувати електронний журнал; 
- реалізовувати принципи безперервного навчання. Студенти в будь який час доби зможуть відвідувати сторінку дисципліни, завантажувати потрібний матеріал, надсилати зроблені завдання, навчатися он-лайн без будь-яких витрат, отримувати постійну підтримку від викладача;

- здійснювати міжнародний обмін досвідом роботи між викладачами.

\section{4. ВИСНОВКИ ТА ПЕРСПЕКТИВИ ПОДАЛЬШИХ ДОСЛІДЖЕНЬ.}

Таким чином, соціальні мережі є додатковим засобом організації спільної роботи студентів та викладачів над навчальним матеріалом; проведення вебінарів; ведення електронних зошитів та форумів; створення в соціальних мережах груп, об' єднаних за спільними ознаками; організації спільного обговорення важливих тем. Регулярне використання соціальних мереж у навчальному процесі сприятиме формуванню культури спілкування студентів у віртуальному середовищі; розвитку комунікативної компетентності й може стати ефективним засобом активізації пізнавальної та навчально-дослідної діяльності студентів - майбутніх вчителів початкової школи; формуванню навичок, зумовлених викликами XXI століття.

Проаналізувавши результати анкетування та тестового контролю знань студентів Київського Університету імені Бориса Грінченка, робимо висновок, що використання соціальних мереж $є$ актуальним та перспективним напрямом в організації навчальної діяльності студентів та активізації навчання інформатичним дисциплінам. Впровадження соціальних мереж сприяє підвищенню мотивації до навчання, індивідуалізації та диференціації навчально-виховного процесу, стимулюванню розвитку творчих здібностей та пізнавального інтересу студентів, колаборації, комунікації, вмінню працювати в колективі.

Перспективи подальших досліджень спрямовані на створення методики використання соціальних мереж у процесі навчання майбутніх вчителів початкової школи інформатичним дисциплінам, розробку методичних рекомендацій щодо використання соціальних мереж у процесі навчання майбутніх вчителів початкової школи інформатичним дисциплінам.

\section{СПИСОК ВИКОРИСТАННИХ ДЖЕРЕЛ}

1. Биков В. Ю. Відкрите навчальне середовище та сучасні мережні інструменти систем відкритої освіти / В. Ю. Биков // Науковий часопис НПУ імені М. П. Драгоманова. Серія 2 : Комп'ютерноорієнтовані системи навчання . - 2010. - №. 9. - С. 9-15. - Режим доступу: http://nbuv.gov.ua/jpdf/Nchnpu_2_2010_9_4.pdf.

2. Биков В. Ю. Сучасні завдання інформатизації освіти / В. Ю. Биков / Інформаційні технологій і засоби навчання - 2010. - № 1(15). - [Електронний ресурс]. - Режим доступу: http://www.nbuv.gov.ua/e-journals/ITZN/em15/emg.html. - Заголовок з екрана

3. Бодненко Д. Н. The Role of Informatization in the Change of Higher School Tasks: the Impact on the Professional Teacher Competences [Електронний pecypc] / Д. Бодненко // IКТ в освіті, дослідженнях і промислі: інтеграція, гармонізація та передача знань.: матеріали Міжнародної конференції ICTERI-2013 (Херсон, 19-22 червня, 2013) - Херсонський державний університет, Херсон, Україна. $\quad$ - 2013.20 Режим http://citeseerx.ist.psu.edu/viewdoc/download?doi=10.1.1.415.8504\&rep=rep1\&type=pdf.

4. Головань М. С. Розвиток пізнавальної активності учнів в процесі навчання алгебри і початку аналізу на основі НІТ : дис. ... канд. пед. наук : 13.00 .02 / Головань Микола Степанович. - К., 1997. - $177 \mathrm{c}$.

5. Жалдак М. I. Педагогічний потенціал впровадження дистанційних форм навчання // Матеріали науково-методичного семінару «Інформаційні технології в навчальному процесі». - Одеса: Вид. BMB, 2009. - C. 6-8. 
6. Клименко О. А. Социальные сети как средство обучения и взаимодействия участников образовательного процесса / О. А. Клименко // Теория и практика образования в современном мире: материалы междунар. науч. конф. (г. Санкт-Петербург, февраль 2012 г.). - СПб.: Реноме, 2012. - C. 405-407. www.moluch.ru/conf/ped/archive/21/1799/.

7. Кучаковская Г. А. Застосування соціальних мереж в навчальній діяльності студентів [Електронний ресурс] / Г. А. Кучаковська / Наукова молодь-2014: матеріали II Всеукраїнської науковопрактичної конференції молодих учених (11 груд. 2014 р) - Інститут інформаційних технологій та засобів навчання НАПН України, Київ - 2014. - Режим доступу: http://conf.iitlt.gov.ua/Images/Files/G_78_1417539443_file.Kuchakosvka_Soc_78_1417539443_file.mer eszi v navchanny_78_1417539443_file.docx.

8. Кучаковська Г. А. Моделі створення бази знань експертної системи з вибору спеціальності для абітурієнтів вищого навчального закладу [Електронний ресурс] / Г. А. Кучаковська // Освітологічний дискурс. - $2014 . \quad-\quad$ №. 1(5). Режим доступу: http://elibrary.kubg.edu.ua/4127/1/H_Kuchakovska_OD_1\%285\%29_IS.pdf.

9. Кучаковська Г. А. (2014) Експертні системи як засіб підвищення ефективності проведення профорієнтаційної роботи [Електронний ресурс] - Інформаційні технології - 2014 : $3 б$. тез I Української конференції молодих науковців, 22-23 трав. 2014 р., м. Київ. С. 31-33. Режим доступу: http://elibrary.kubg.edu.ua/3751/.

10. Лузан П. Г. Теоретичні і методичні основи формування навчально-пізнавальної активності студентів у вищих аграрних закладах освіти [Текст] : Дис... д-ра пед. наук: 13.00.04 / Лузан Петро Григорович ; Національний аграрний ун-т. - К., 2004. - 505 арк.

11. Манькевич Т. В. Аналіз стану дослідження активізації пізнавальної діяльності студентів вищих навчальних закладів [Електронний ресурс] / Т. В. Манькевич // Проблеми інженерно-педагогічної

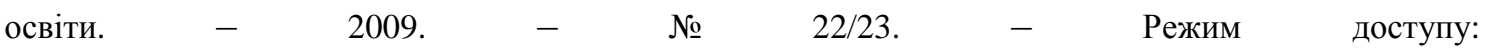
http://repo.uipa.edu.ua/jspui/bitstream/123456789/832/3/T_\%20\%D0\%9Cankevich.pdf.

12. Про Національну стратегію розвитку освіти в Україні на період до 2021 року [Електронний pecypc]. - Режим доступу: http://zakon4.rada.gov.ua/laws/show/344/2013.

13. Рейтинг соцсетей: Facebook - первый в мире, а ВКонтакте - в Европе [Електронний ресурс]. Режим доступу: http://korrespondent.net/business/web/3284321-reitynh-sotssetei-Facebook-pervyi-vmyre-a-vkontakte-v-evrope.

14. Свойства социальных сетей [Электронный ресурс]. - Режим доступа: http://www.sdcompany.su/article/ computers/social.

15. Спірін О. М. Моделі гармонізації мережних інструментів організації та інформаційнотехнологічного підтримування навчально-пізнавальної діяльності [Електронний ресурс] /

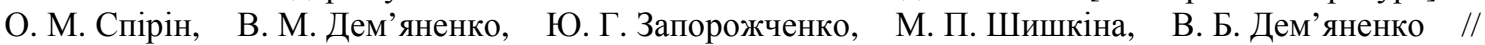
Інформаційні технології і засоби навчання. - 2012. - № 6 (32). Режим доступу: http://journal.iitta.gov.ua/index.php/itlt/article/view/774/580.

16. Стратегія розвитку інформаційного суспільства в Україні. [Електронний ресурс]. - Режим доступу: http://zakon2.rada.gov.ua/laws/show/386-2013-p\#n8.

17. Тверезовська Н. Т. Роль і місце соціальних мереж у формуванні освітньо-інформаційного середовища аграрних університетів / Н. Т. Тверезовська, С. М. Мигович // Науковий вісник Національного університету біоресурсів і природокористування України. Серія : Педагогіка, психологія, філософія . - 2012. - Вип. 175(3). - С. 291-298. - Режим доступу: http://nbuv.gov.ua/jpdf/nvnau_ped_2012_175(3)_42.pdf.

18. Фещенко А. В. Социальные сети в образовании: анализ опыта и перспективы развития / Открытое дистанционное образование, №3 (43). 2011 г. - Томск: ТГУ, АСОУ, 2011. - С. 44 - 49.

19. Яндекс з'ясував, скільки українців сидять у соцмережах [Електронний ресурс]. - Режим доступу: http://tech.obozrevatel.com/news/18765-yandeks-vyiyasnil-skolko-ukraintsev-sidyat-v-sotssetyah.htm.

Матеріал надійшов до редакиії 25.03.2015 p.

\section{РОЛЬ СОЦИАЛЬНЫХ СЕТЕЙ В АКТИВИЗАЦИИ ПРОЦЕССА ОБУЧЕНИЯ БУДУЩИХ УЧИТЕЛЕЙ НАЧАЛЬНОЙ ШКОЛЫ ИНФОРМАТИЧЕСКИМ ДИСЦИПЛИНАМ}

\section{Кучаковская Галина Андреевна}

преподаватель кафедры информационных технологий и математических дисциплин Киевский университет имени Бориса Гринченко, г. Киев, Украина 


\begin{abstract}
Аннотация. В статье проанализированы подходы к использованию социальных сетей в процессе обучения информатическим дисциплинам; описано дидактические возможности использования социальных сетей во время проведения лекционных и практических занятий по информатическим дисциплинам; проанализированы и представлены результаты анкетирования студентов специальности «Начальное образование» по использованию социальных сетей в учебной деятельности и повседневной жизни; проведен статистический анализ результатов педагогического эксперимента по внедрению социальных сетей в учебный процесс будущих учителей начальной школы. Установлено, что их популярность среди молодежи может получить новые формы реализации и методы использования в процессе обучения информатическим дисциплинам.
\end{abstract}

Ключевые слова: учебный процесс; будущие учителя начальной школы; информационное общество; информатические дисциплины; ИКТ; облачные технологии; социальные сети.

\title{
THE ROLE OF SOCIAL NETWORKS FOR THE ACTIVIZATION THE LEARNING PROCESS OF INFORMATICS FUTURE PRIMARY SCHOOL TEACHERS
}

\author{
Halyna A. Kuchakovska \\ lecturer, Department of Information Technologies and Mathematical Disciplines \\ Borys Grinchenko Kyiv University, Kyiv, Ukraine \\ h.kuchakovska@kubg.edu.ua
}

\begin{abstract}
The article analyzes the approaches of the use of social networks in learning processes of informatics; it has been described the didactical possibility of using social networks during the lecture and practical lessons; the results of the questionnaire of students of specialty "Primary education «about the use of social networks in learning activities and in daily life are presented; statistical analysis of the implementation of network services in the educational process is conducted. It is noted that their popularity among young people can open new ways of realization and methods of their use in the learning process of informatics.
\end{abstract}

Key words: educational process; future primary school teacher; information society; informatics; ICT; cloud technologies; social networks.

\section{REFERENCES (TRANSLATED AND TRANSLITERATED)}

1. Bykov V. U. Open learning environment and modern networking tools of open education. [online] / V. Bykov/ Scientific journal NEA Dragomanov. Seria 2: Computer-oriented education system/ - 2010.№9.-p.9-15. - Available from: http://enpuir.npu.ed u.ua/bitstream/123456789/703/1/2.pdf (in Ukrainian).

2. Bykov V. U. Modern tasks of informatization of education [online] / V. U. Bykov // Information technology and learning tools. - 2010. - №1(15). - Available from: http://lib.iitta.gov.ua/1162/ (in Ukrainian).

3. Bodnenko D. The Role of Informatization in the Change of Higher School Tasks: the Impact on the Professional Teacher Competences. [online] / D. Bodnenko // Materials of International Conference «ICT in Education, Research, and Industrial Applications: Integration, Harmonization, and Knowledge Transfer» ICTERI - 2013 (Kherson, June 19-22, 2013) Kherson State University, Kherson, Ukraine. 2013.

from: http://citeseerx.ist.psu.edu/viewdoc/download?doi=10.1.1.415.8504\&rep=rep1\&type=pdf (in English).

4. Holovan M. S. Development of cognitive activity of pupils in learning process of algebra and calculus on based on NIT: Dissertation Candidate of Pedagogy: 13.00.02 / Holovan Mykola Stepanovych. - K., 1997. - 177p. (in Ukrainian).

5. Zhaldak M. I. The pedagogical potential introduction of distance learning // Materials of scientificmethodical seminar «Information technology in the educational process» 8 (in Ukrainian).

6. Klymenko O. A. Social networks as a means of learning and interaction between the participants of the educational process [online] / O. A. Klymenko // Theory and practice of education in the modern world: 
Material International Scientific Conference (Saint Petersburg, February 2012). - SPb.: Renome, 2012. P.405-405. Available from: www.moluch.ru/conf/ped/archive/21/1799/. (in Russian)

7. Kuchakovska H. A. The use of of social networks in the educational process of students [online] / H. A. Kuchakovska / Scientific youth - 2014: Material II All-Ukrainian scientific-practical conference of Young Scientists (11 December 2014) - Institute of Information technology and learning tools NAPS of Ukraine, Kyiv - $\quad 2014 . \quad$ Available from: http://conf.iitlt.gov.ua/Images/Files/G_78_1417539443_file.Kuchakosvka_Soc_78_1417539443_file.mer eszi_v_navchanny_78_1417539443_file.docx (in Ukrainian).

8. Kuchakovska H. A. The models of the knowledge base expert system for applicants choosing a specialty in high schools [online] / H. Kuchakovska // Osvitolohichnyi dyskurs. - 2014. - №1(5). . - Available from: http://elibrary.kubg.edu.ua/4127/1/H_Kuchakovska_OD_1\%285\%29_IS.pdf (in Ukrainian).

9. Kuchakovska H. A. (2014) Improving career guidance through the use of expert systems [online] / Information technologies - 2014: All Ukrainian Conference of Young Scientists, May 22-23 2014, Kyiv, p.31-33. - Available from: http://elibrary.kubg.edu.ua/3751/ (in Ukrainian).

10. Luzan P. H. Theoretical and methodological bases of formation of teaching and learning activities of students in higher agricultural education institutions: dissertation Doctor of Pedagogy: 13.00.04 / Luzan Petro Hryhorovych: National Agricultural University. - K., 2004. - 505 p. (in Ukrainian).

11. Mankevich T. Analysing the State of Investigating a Cognitive Activity Activization of Higher Educational Institutions Students [online] / T. V. Mankevich // Problems of Engineering and Teacher Education. $\quad-\quad 2009 . \quad$ - $\quad 2 \quad$ №22/23. $\quad$ - $\quad$ Available http://repo.uipa.edu.ua/jspui/bitstream/123456789/832/3/T_\%20\%D0\%9Cankevich.pdf (in Ukrainian).

12. National strategy for education development until 2021. [online] - Available from: http://zakon4.rada.gov.ua/laws/show/344/2013 (in Ukrainian).

13. Rating Social Networks: Facebook - First in the world, and VKontakte - in Europe [online]. - Available from: http://korrespondent.net/business/web/3284321-reitynh-sotssetei-Facebook-pervyi-v-myre-avkontakte-v-evrope (in Russian).

14. Properties Social Networks Students [online] - Available from: http://www.sd-company.su/article/ computers/social (in Ukrainian).

15. Spyryn O. M. Models of harmonizing of network tools of organization and information technological support of learning and cognitive activity [online] / O. Spirin, V. Demyanenko, Y. Zaporozhchenko, M. Shyshkina, V. Demyanenko // Information technology and learning tools. - 2012 - №6(32) . Available from: http://journal.iitta.gov.ua/index.php/itlt/article/view/774/580 (in Ukrainian).

16. Strategy of Information Society Development in Ukraine. [online] - Available from: http://zakon2.rada.gov.ua/laws/show/386-2013-p\#n8 ( in Ukrainian).

17. Tverezovska N. T. Role of social networks in shaping educational and informative environment agrarian universities: Article [online] / S. M. Mugovuch, N. T. Tverezovska // Scientific Bulletin NUBiPseries "Pedagogy, Psychology, Philosophy." - Issue 175, Part 3. - Kyiv, 2012. - Available from: http://www.mnau.edu.ua/ua/02_02_01_10_mygovich.-html\#ixzz2wnSKAKKp. - Dateofaccess 25.05. 2014 (in Ukrainian).

18. Feshchenko A. V. Social networks in education: analysis of the experience and perspectives of development / Open Distance Education. №3 (43) 2011. - Tomsk: TGU, ACOY, 2011. - p. $44-49$ (in Russian).

19. Yandex find out how many Ukrainians sit in social networks [online] - Available from: http://tech.obozrevatel.com/news/18765-yandeks-vyiyasnil-skolko-ukraintsev-sidyat-v-sotssetyah.htm (in Russian). 